\title{
Droughts and floods in Malawi: impacts on crop production and the performance of sustainable land management practices under weather extremes
}

Nancy McCarthy, ${ }^{1}$ (D) Talip Kilic, ${ }^{2 *}$ Josh Brubaker, ${ }^{1}$ Siobhan Murray, ${ }^{2}$ and Alejandro de la Fuente ${ }^{3}$

${ }^{1}$ Lead Analytics, Washington, DC, USA $;{ }^{2}$ Development Data Group, The World Bank, Washington, DC, USA and ${ }^{3}$ Poverty and Equity Global Practice, The World Bank, Washington, DC, USA

${ }^{*}$ Corresponding author. E-mail: tkilic@worldbank.org

(Submitted 29 August 2019; revised 31 March 2020, 8 July 2020; accepted 30 August 2020; first published online 25 January 2021)

\begin{abstract}
Climate change is predicted to increase the frequency of extreme weather events, increasing the vulnerability of smallholder farmers dependent on rain-fed agriculture. We evaluate the extent to which farmers in Malawi suffer crop production losses due to extreme weather, and whether sustainable land management (SLM) practices help shield crop production losses from extreme events. We use a three period panel dataset where widespread floods and droughts occurred in separate periods, offering a unique opportunity to evaluate impacts using data collected immediately following these events. Results show that crop production outcomes were severely hit by both floods and droughts, with average losses ranging between 32-48 per cent. Legume intercropping provided protection against both floods and droughts, while green belts provided protection against floods. However, we find limited evidence that SLM adoption decisions are driven by exposure to weather shocks; rather, farmers with more productive assets are more likely to adopt.
\end{abstract}

Keywords: climate change; crop production; sustainable land management; Malawi

JEL classification: D01; Q12; Q25; Q54

\section{Introduction}

Rural households in Malawi face extremely difficult circumstances that limit their ability to achieve lasting improvements in food security. Rural poverty rates are high at 41 per cent (World Bank, 2016), and most farm households have very small landholdings and are reliant on rainfed agriculture (Ricker-Gilbert et al., 2014; Asfaw et al., 2016). Thus, farmers are currently vulnerable to extreme weather events, such as the floods that occurred during the 2014/2015 growing season and the drought that occurred during the 2015/2016 growing season. The Malawi Vulnerability Assessment Committee (MVAC)

(C) The World Bank. Published by Cambridge University Press. This is an Open Access article, distributed under the terms of the Creative Commons Attribution licence (http://creativecommons.org/licenses/by/4.0), which permits unrestricted re-use, distribution, and reproduction in any medium, provided the original work is properly cited. 
forecasted that over 2.8 million people (17 per cent of the population) in 17 floodaffected districts would not be able to meet their food requirements over the period April 2015-March 2016 (MVAC, 2015), while over 6.5 million people (39 per cent of the population) in 24 drought-affected districts were forecasted to be unable to meet their food requirements during the April 2016-March 2017 period (MVAC, 2015, 2016). At the same time, it is expected that farmers' exposure to extreme climate events will continue to increase (Blanc, 2012; Belloumi, 2014; Venäläinen et al., 2016).

Currently, there is limited household survey-based empirical evidence of the impacts of extreme weather events on crop production, or the factors that mitigate the negative impact of extreme weather events. In this paper, we use data from the 2013 and 2016 waves of the Malawi Integrated Household Panel Survey (IHPS), which is statistically representative at the national- and urban/rural-levels. Additionally, we use data collected primarily in the Southern Region, as part of the Flood Impact Assessment Survey (FIAS). The analysis focuses on the impacts of extreme rainfall on maize yields and the value of crop production per hectare. We are also interested in determining whether adoption of sustainable land management (SLM) practices reduce crop losses in the face of extreme weather events. Our dataset includes information on four SLM practices used in the analysis: minimum soil disturbance tillage, legume intercropping, stone or earthen bunds, and planting vetiver grass or trees on plots (hereafter referred to as green belts).

We run two sets of analyses. In the first set, we estimate crop production outcomes, including the SLM variables as well as interaction terms with extreme weather dummies, to evaluate whether these practices were effective in reducing production losses under extreme weather conditions. In the second set, we estimate the determinants of SLM adoption.

The results show large negative impacts of drought and flood shocks on maize yields and value of crop production per hectare, with drought-induced maize yield declines of 32-34 per cent and value per hectare declines of 42-44 per cent. The flood shock was even more severe, leading to 54 per cent lower maize yields and 58 per cent lower value per hectare. Of the four SLM practices, only legume intercropping had a direct positive impact on value per hectare. Legume intercropping also led to higher maize yields and crop production per hectare under both drought and flood shocks, reducing losses to 15-18 per cent under the drought shock and to no loss under the flood shock. However, exposure to floods and shocks had limited impacts on adoption decisions. Instead, farmers with larger plots and more productive assets were also more likely to adopt SLMs.

Our results contribute to the literature in three main ways. First, they contribute to a small but growing literature that combines weather and climate variables with household crop production data in order to create objective measures of both current period weather shocks and long-term climate patterns, and to test their impacts on crop production and SLM adoption. Our three-period panel data includes two years when droughts and floods affected a large number of households, so we did not have to rely on recall data to tease out the impacts of extreme weather events. Second, our analysis assesses the impacts of SLMs - and their interaction with flood and drought shocks - on production outcomes. The empirical evidence on the effectiveness of SLMs in shielding crop production from extreme weather induced losses is both relatively scarce and mixed; our results are also mixed, with only robust positive impacts for legume intercropping. Third, our results show that exposure to rainfall shocks is not driving adoption of SLMs in general. These results contribute to the evidence base needed to support those advocating for more concerted efforts to enable vulnerable smallholders adapt to climate change. 


\section{Literature review}

Despite a rich theoretical literature documenting the potential negative impacts of uninsured weather extremes on crop outcomes (Hardaker et al., 2004; Hurley, 2010), until very recently, there has been little empirical evidence of the magnitude of their impacts on crop outcomes, particularly studies using household-level data, which is the focus of this literature review. More recent studies for Sub-Saharan African countries show large negative impacts of droughts on crop production and incomes, highlighting how vulnerable smallholders are to extreme weather events. Alfani et al. (2019) find that drought reduced maize yields by 29-41 per cent in Zambia; McCarthy et al. (2018) find that severe flooding reduced value of crop production per hectare 52 per cent in Malawi; Micheler et al. (2019) find that drought reduced maize yields by 50-80 per cent in Zimbabwe; and Wineman et al. (2017) find that droughts reduced crop income per capita by 29 per cent in Kenya.

SLM techniques have long been promoted as measures to reduce production losses associated with extreme weather events. Such measures include minimum tillage, soil and water conservation structures, permanent soil cover and agro-forestry. As thoroughly reviewed in Blanco and Lal (2008), adoption of the SLM practices we observe in our dataset should mitigate crop production losses due to weather extremes by protecting soil quality through reducing erosion and improving soil structure, soil nutrient levels, water retention capacity and drainage (see chapters 8-11 in particular). Cultivated plots with better soil quality are more likely to absorb weather shocks than those with highly degraded soils (Mattee et al., 2015; Nkonya et al., 2015).

Empirical evidence on whether these SLMs actually reduce production losses using household survey data is scant, especially under extreme weather shocks. Arslan et al. (2015) find that legume intercropping increases yields by about 24 per cent on average, and that the benefits to legume intercropping increase as maximum seasonal temperatures increase. Asfaw et al. (2016) find that legume intercropping combined with inorganic fertilizer and trees increases maize yields; however, they find a negative impact from the adoption of soil and water conservation structures. The authors note that there were few areas subject to relatively extreme weather patterns, and surmise that such structures may only provide positive benefits during more extreme weather conditions than observed in the dataset. Micheler et al. (2019) find in Zimbabwe that adoption of 'conservation agriculture' (minimum soil disturbance tillage, permanent soil cover and crop rotation), does not result in higher yields in 'normal' years but does lead to higher yields when rainfall deviates from expected rainfall.

McCarthy et al. (2011) provide a broader review of the empirical evidence documenting impacts of SLM techniques on both yields and yield variability, and conclude that the evidence for most SLMs is quite mixed. This is partially because different SLM practices can have different impacts on crop production depending on whether droughts or flooding occurs. For instance, Dutilly-Diane et al. (2003) found that farmers in semi-arid regions of Burkina Faso who had invested in stone bunds in low rainfall areas had 41 per cent higher sorghum/millet yields, but those in moderate and high rainfall areas actually had lower yields. A number of studies in different agro-ecological zones of Ethiopia have found that many SLMs have a positive impacts on crop production in low productivity areas but do not provide benefits under more favorable agro-ecological conditions (Benin, 2006; Kassie et al., 2008; Pender and Gebremedhin, 2008; Kassie et al., 2010; Kato et al., 2011). 


\section{Empirical framework}

\subsection{Empirical strategy}

Drawing on the expected utility models of crop production decisions of risk averse decision-makers (Just and Zilberman, 1983; Ramaswami, 1992; Chavas and Holt, 1996), we can write our crop production estimating equation as follows:

$$
\begin{aligned}
Y_{i j t}= & \alpha+\beta_{1} \hat{W}_{i}+\beta_{2} \sigma_{W, i}^{2}+\beta_{3} M_{i t}\left(\frac{W^{A}}{\hat{W}}\right)+\beta_{4} X_{i j t}^{T}+\beta_{5} X_{i j t}^{S L M} \\
& +\beta_{6}\left(X_{i j t}^{S L M} * M_{i t}\left(\frac{W^{A}}{\hat{W}}\right)\right)+\beta_{7} Z_{i t}+\mu_{Y, i}+\varepsilon_{Y, i j t},
\end{aligned}
$$

where $Y_{i j t}$ is crop production by household $i$ on plot $j$ in time period $t ; \hat{W}_{i}$ are measures of expected weather and $\sigma_{W, i}^{2}$ is the variance of weather measures; and $M_{i t}\left(W^{A} / \hat{W}\right)$ captures metrics of the difference between actual weather realized and expected weather (weather deviations). Because plots are often quite close, and given the resolution of the weather data, we drop the plot subscript, $j$, from the climatic variables, since this better captures the fact that these variables are nearly perfectly correlated at the household level. $X_{i j t}^{T}$ is a vector of traditional inputs; $X_{i j t}^{S L M}$ is a vector of SLM inputs; $X_{i j t}^{S L M \text {,* * }}$ $M_{i j t}\left(W^{A} / \hat{W}\right)$ is a vector of SLM inputs interacted with weather deviations; $Z_{i t}$ is a vector of household and community characteristics that affect crop production outcomes; and $\alpha, \beta_{1}-\beta_{7}$ are parameters to be estimated. $\mu_{Y, i}$ capture unobserved, time-invariant household characteristics affecting crop production, and $\varepsilon_{Y, i j t}$ is the time-varying error term, assumed to be normally i.i.d.

The SLM adoption equations are similar, but without current period weather shocks:

$$
\operatorname{SLM}_{i j t}=\delta+\kappa_{1} \hat{W}_{i j}+\kappa_{2} \sigma_{W i j}^{2}+\kappa_{3} Z_{i t}+\mu_{\mathrm{SLM}, i}+\varepsilon_{\mathrm{SLM}, i j t} .
$$

The variables are identified as above, $\delta, \kappa_{1}-\kappa_{3}$ are parameters to be estimated; $\mu_{\text {SLM }, i}$ capture unobserved, time-invariant household characteristics affecting SLM adoption, and $\varepsilon_{\text {SLM }, i j t}$ is the time-varying error term, assumed to be $\sim N\left(0, \sigma_{\text {Yit }}^{2}\right)$. Because we do not observe the extent of SLM applied on the plot, we run panel linear probability models using dummy variables for SLM adoption.

While SLM adoption decisions may well be endogenous to the crop production outcomes, the SLM, weather-shock interaction terms are conditionally exogenous (Lewbel, 2012; Nizalava and Mirtazashvili, 2016). Decisions on whether to adopt or maintain all four SLM practices are made at the beginning of the season. Thus, because we control for expected rainfall conditions (mean and variance of rainfall), the impact of the SLMs under weather shocks on crop production outcomes is exogenous conditional on expected rainfall variables.

We estimate the above equations using both correlated random effects (CRE) and household fixed effects (FE) for the crop production outcomes and SLM adoption regressions. The FE model directly controls for time-invariant omitted relevant variables using differences, while the CRE model controls for these by using time averages of observed variables to capture unobserved heterogeneity (Wooldridge, 2010; Schunck, 2013). The CRE model is more flexible in that it allows one to include time-invariant variables, which is of particular relevance for the SLM adoption equations where climate conditions are hypothesized to be important factors in driving adoption. Below, we report 
Table 1. Number of plot observations, by Long Panel and FIAS samples

\begin{tabular}{|c|c|c|c|c|}
\hline & \multicolumn{2}{|c|}{ 2013/16 Long Panel } & \multicolumn{2}{|c|}{ 2013/15/16 FIAS } \\
\hline & All & Maize & All & Maize \\
\hline IHPS 2013 & 2,837 & 1,990 & 1,234 & 1,015 \\
\hline FIAS 2015 & & & 527 & 424 \\
\hline IHS4 2016 & 3,600 & 2,650 & 1,585 & 1,296 \\
\hline Total & 6,437 & 4,640 & 3,346 & 2,735 \\
\hline
\end{tabular}

results using the CRE model for both crop production outcomes and SLM adoption, while the full FE results are available in online appendices 2 and 3. In all specifications, we use cluster-robust standard errors.

As noted above, the 2015 FIAS sample was concentrated in the Southern Region and included households that were not necessarily in the 2013-2016 Long Panel. This does pose some issues for constructing the three-period panel. We ran three specifications with three different samples: (1) A 2013-2016 only specification, that includes all households in the 2013-2016 Long Panel covering all regions in the country; (2) a specification that includes all 2013 Long-Panel households located in FIAS districts in 2013 and their corresponding 2016 panel households, plus all available FIAS households, whether in the Long Panel or not; and (3) the same as (2), but restricting FIAS households to those that are also in the Long Panel. There are few differences in results between the 2 nd and 3 rd samples, so in the text we only report results for the 1st and 3rd samples.

\subsection{Data and variables used in the analysis}

We use data from the 2013 and 2016 waves of the IHPS. The IHPS was implemented by the National Statistical Office, as part of the World Bank Living Standards Measurement Study-Integrated Surveys on Agriculture initiative. The dataset includes 1,907 households that were interviewed in 2013, and 2,507 households that were interviewed in 2016 and that could be traced back to the 1,907 households in 2013 as part of the Long Panel sample. There are more households in 2016 since some households in 2013 had split into two or more households by 2016, and all split households were interviewed. ${ }^{1}$ For the three-period panel, we retain observations that were followed in all three periods, which include 667, 273 and 837 households in 2013, 2015 and 2016, respectively. Table 1 gives the number of cultivated plots and number of maize plots observed in each year, for the two samples.

\subsection{Explanatory variables}

\subsubsection{Weather and climate variables}

We include several weather and climate variables in order to control for the impacts of rainfall on crop outcomes, using the National Oceanic and Atmospheric Administration (NOAA) African Rainfall Climatology version 2 (ARC2) dataset. Following the empirical

\footnotetext{
${ }^{1}$ The household-level attrition rate between 2013 and 2016 was 4 per cent.
} 
model above, we include expected flowering period rainfall ${ }^{2}$ and the coefficient of variation of flowering period rainfall to control for farmers' expected weather realizations on crop production outcomes, and the percentage difference of the current year's rainfall from expected rainfall to control for deviations from expected rainfall. ${ }^{3}$

We also allow for non-linear impacts of droughts in 2016 and floods in 2015 on crop production by including two variables to capture these shocks. With respect to agricultural droughts, there is no agreement on which specific variable from which specific data source should be used (Dalezios et al., 2017; Hao et al., 2017). We systematically explored a number of variables to capture drought using the ARC2 data, the Climate Hazards Group InfraRed Precipitation with Station (CHIRPS) data, as well as NOAA's normalized difference vegetation index (NDVI), the standardized precipitation index (SPI) and the standardized precipitation evapotranspiration index (SPEI). Measures created from the SPI and SPEI did have expected negative impacts in some specifications, while measures created from CHIRPS and the NDVI datasets were generally not significant. A range of different measures based on the ARC2 dataset are negative and significant. Our systematic evaluation of the performance of different drought measures led us to choose a semi-continuous measure, which had robust and significant negative impacts across alternative specifications. Specifically, our drought shock variable takes a value of zero when flowering season rainfall is less than 30 per cent below the long-term mean, and takes the absolute value of the percentage difference for differences greater than or equal to 30 per cent below the long-term mean. This measure captures an initial negative threshold effect at 30 per cent, and also allows for additional losses due to shocks greater than 30 per cent. There were no observations with such extreme drought conditions in 2013 or 2015, while over 35 per cent of plot-level observations experienced drought conditions in 2016.

To best capture the impacts of floods, we use a measure of mean flood intensity, defined as the water depth (in $\mathrm{mm}$ ) above a flood threshold, derived from the Global Flood Monitoring System hydrological runoff and routing model developed at the University of Maryland (Merz et al., 2007). It is positively correlated with December-January rainfall, but also captures underlying hydrology and so should better capture flood events. However, the flood intensity measure alone is somewhat coarse, at about $8 \mathrm{~km}$ squared resolution. Because we have information on elevation and distance to the nearest water body at the homestead, we performed a principal components analysis of these two characteristics and mean flood intensity. After exploring a number of flood shock measures, we chose to define a flood shock as occurring if the flood index was greater than 30 per cent above the average flood index value.

For the SLM adoption equations, instead of using the coefficient of variation of rainfall, we use the probability of experiencing a drought and the probability of receiving a flood. While the coefficient of variation captures the range of potential realizations

\footnotetext{
${ }^{2}$ Total flowering season rainfall covers the 5 th-8th dekads (a dekad is defined as a 10-day period) following onset of the rainy season. Onset was defined as the first dekad with $25 \mathrm{~mm}$ of rainfall that was followed by a dekad with $20 \mathrm{~mm}$ rainfall, starting any time after October 1 (Nicholson et al., 2013).

${ }^{3}$ We evaluated the robustness and predictive power of a number of different time periods within the season and determined that variables covering the flowering period were consistently robust and significantly negative across alternative specifications, while total period rainfall was almost never significant. This is also consistent with the agronomic literature, which shows that the flowering period is the period when maize crops have the highest water requirements (see the FAO webpage at http://www.fao.org/land-water/ databases-and-software/crop-information/maize/en/).
} 
affecting crop production outcomes and is consistent with expected utility models, the probabilities of droughts and floods better capture exposure to extreme weather events that may drive the threshold decision to adopt SLMs.

Finally, we also include a measure of temperature shocks. Research has shown that high temperatures have 'threshold' impacts on maize yields; temperatures above which have significant negative impacts on yields (Schlenker and Lobell, 2010; Hatfield, 2016). To capture threshold effects, we use historical data on maximum midnight temperatures obtained from the European Centre for Medium-Range Weather Forecasts ERA-Interim reanalysis model dataset. The empirical literature suggests that the number of dekads where maximum midnight temperatures were greater than $28^{\circ} \mathrm{C}$ during the growing season captures negative impacts on crop production, and so we include this as a measure of high temperature shocks (Hatfield, 2016; Steward et al., 2018).

\subsubsection{SLM practices}

Given available data from the questionnaire, we include four dummy variables for the SLM practices: (1) minimum soil disturbance (MSD) tillage, (2) legume intercropping, (3) stone or earthen bunds, and (4) green belts (either trees or vetiver grass on the plot). We then create interaction terms for each of the four SLM dummies with both the flood and drought shocks.

Other authors have argued that combinations of practices may be required in order to generate benefits, such as the three components of conservation agriculture (CA) (Kassie et al., 2015; Ward et al., 2018). With respect to CA specifically, we do not have data on crop rotation, but we do have information on permanent crop cover. However, less than 0.6 per cent of plots combined both minimum soil disturbance and permanent crop cover, so there is not sufficient variation to probe this further. Among the four SLM practices included in the analysis, farmers tended to adopt only one practice per plot, and so it was not possible to test whether different bundles of SLMs performed differently.

\subsubsection{Additional control variables}

3.3.3.1 Plot characteristics We include plot size in natural logarithms; a dummy that captures whether plot slope is moderately or very steep (vis-à-vis flat or slight); dummies for sandy and clay soils versus omitted loamy soils; a dummy for whether the plot is owned, and a dummy for whether the plot can be sold or used for collateral. We also include plot management characteristics, such as dummies for whether the plot is managed by a woman or jointly managed by a man and woman, vis-à-vis the omitted category, managed by a man; and age of the primary plot manager. For crop production, we expect land size to be negative, reflecting diminishing returns to scale; and favorable characteristics (less steep slopes, male manager, owned, can be sold/used for collateral) to be positive. For SLM adoption, we expect plot size, owned and can be sold/used for collateral to be positive, and we expect that less favorable characteristics may increase SLM adoption, e.g., steeper slopes more vulnerable to erosion. Signs for other co-variates are generally ambiguous, for instance, age may increase yields due to experience, but may decrease adoption of more labor-intensive SLMs.

3.3.3.2 Production inputs Production inputs include the number of adults, in natural logarithms, to proxy for household labor and a dummy for whether hired labor was used; the number of weedings performed; a dummy for whether any pesticide or herbicide was used on the plot; and a dummy for the use of organic fertilizer. Following Battese (1997), to account for plots that did not have inorganic fertilizer, we include a dummy variable 
equal to one where fertilizer was not applied, and then include the logged quantity of fertilizer used. ${ }^{4}$ For the maize yield regressions, we included the quantity of seeds (logs). For the value of crop production regressions, we include a dummy for whether the household planted cash crops, such as cotton or tobacco. We expect all production inputs to have a positive impact on crop production outcomes.

\subsubsection{Household demographics and wealth Household demographic variables} include the maximum years of education of any adult in the household and the proportion of adults literate in English, which should increase crop production. They may also increase adoption of SLMs, since education and literacy should increase the ability to obtain information and adapt practices to local conditions. We include dummies from whether the head and/or spouse are disabled, which should decrease both crop production and adoption of SLM.

A wealth index was created from a principal component factor analysis of consumer durables and household dwelling characteristics, and an index of agricultural implements owned by the household was also created from a principal component factor analysis. We include the number of mobile phones owned by household members and a dummy for whether any member of the household has an account at a financial institution. All of these variables are hypothesized to increase crop production and adoption of SLMs by relieving resource constraints.

\subsubsection{Household networks We include the number of adult children living away from home, and three density networks. The questionnaire collected data on the number of connections to input and output markets, distinguishing between 'within community', 'nearby towns', and 'towns and cities further away', and so we include the number of connections at these three levels. Greater networks should increase crop production out- comes through better capacity to source market information and inputs, and increase SLM adoption through greater information flows to enhance learning about the benefits of SLMs and adapting to local conditions.}

\subsubsection{Location characteristics and fixed effects We control for the number of house-} holds in the community; the difference between largest and smallest landholdings in the community to proxy wealth heterogeneity; the proportion of community leaders who are women; the proportion of community leaders with no education; a dummy for whether there is an assistant agricultural extension agent located in the community; a dummy for farm-related groups; an index of community infrastructure and services; and an index that captures the density of road networks and proximity to urban centers (access index). We expect that less heterogeneous communities, with more educated leaders, an extension agent, farmer groups, greater infrastructure and services and greater accessibility will have greater crop production and will be more likely to adopt SLMs. We hypothesize that the proportion of women leaders will also be positive for both crop production and SLM adoption as more female leaders may increase information flows to women farmers.

We include a number of supra-community characteristics including the number of radio stations operating in the district to capture locally relevant information flows that

\footnotetext{
${ }^{4}$ Inorganic fertilizer quantity is combined as a simple sum of all types of inorganic fertilizer applied on plot.
} 
can increase both crop production and SLM adoption; the number of governmentowned Agricultural Development and Marketing Corporation stations in the district, which are expected to increase crop production with ambiguous impacts on SLM adoption; and the percentage of land within the extension planning area that is in estates, which is expected to increase crop production through greater density of marketing opportunities but with ambiguous impacts on SLM adoption.

Finally, to control for any remaining location FEs, we include dummies for the extension planning area. These areas are administrative units lower than districts, and are included to control unobserved local agricultural system characteristics.

\subsection{Descriptive statistics}

Table 2 provides descriptive statistics for dependent and select explanatory variables used in the analysis. ${ }^{5}$ Vis-à-vis 2013, maize yields were 51 and 35 per cent lower in 2015 and 2016, respectively, while value per hectare was 58 and 24 per cent lower in 2015 and 2016, respectively. Looking at the climate and weather variables, we see that average rainfall deviations were substantially higher in 2015 and 2016 than in 2013, at 29 and 33 per cent versus 21 per cent respectively. High temperature shocks were fairly limited in 2013 and 2015, though 6 per cent of the observations received a temperature shock in 2016. Looking at the historical climate variables, we see that the 2015 values, which are based on the smaller FIAS sample concentrated in the Southern Region, show that mean rainfall is lower while rainfall variability and exposure to shocks are higher than the full sample. In fact, both the flood and drought shocks were concentrated in this region.

Looking at our SLM practices, we note that adoption of minimum soil disturbance is low and roughly similar across years, while legume intercropping is relatively high, at 35 per cent in 2013 on average, but dropping to 28 per cent in 2016, a statistically significant decrease. Bunds also decrease similarly over the period 2013 and 2016. Finally, green belts increased from 2013 to 2016, though still at moderate levels of adoption of 9.5 per cent in 2016. Given these adoption rates, weather shock interaction terms are highest for legume intercropping and for bunds, particularly when interacted with the flood shock.

\section{Results and discussion}

\subsection{Maize yield and crop value per hectare results}

Table 3 presents the CRE results for maize yields and gross crop value per hectare at the plot level, controlling for cluster robust standard errors, for both the Long Panel and FIAS samples. Table 3 includes results only for our key variables of interest, but full results are available in the online appendix. Hereafter, we refer to the 2013-2016 Long Panel sample as the Long Panel and the 2013-2015-2016 FIAS Long Panel sample as FIAS. We first note the strong negative impact of the 2015 and 2016 time dummies on crop production, reflecting an overall reduction in yields between 2013 and 2015, 2016, with only the 2016 dummy insignificant in the FIAS value per hectare equation. The drought shock led to further significant reductions in maize yields and value of crop production per hectare across all samples. All else equal, the drought shock led to 32-34 per cent lower maize yields and between 42-44 per cent lower value per hectare. While negative for both, the drought shock had significantly greater negative impacts on value

\footnotetext{
${ }^{5} \mathrm{~A}$ full table of descriptive statistics is provided in the online appendix.
} 
Table 2. Descriptive statistics by year, select variables

\begin{tabular}{|c|c|c|c|c|c|c|c|c|c|}
\hline & \multicolumn{3}{|c|}{2013} & \multicolumn{3}{|c|}{2015} & \multicolumn{3}{|c|}{2016} \\
\hline & $N$ & Mean & SE & $N$ & Mean & SE & $N$ & Mean & SE \\
\hline \multicolumn{10}{|l|}{ Ag Production Vars, Plot Level } \\
\hline Maize Yield & 1,990 & 1,805 & 48.38 & 424 & 776 & 42.439 & 2,651 & 1,135 & 24.336 \\
\hline Value Per Ha. (100 K MWK) & 2,837 & 331 & 7.93 & 527 & 125 & 6.15 & 3,601 & 247 & 4.61 \\
\hline \multicolumn{10}{|l|}{ Weather and Climate } \\
\hline Abs. Rainfall Deviations & 2,837 & 0.208 & 0.003 & 527 & 0.326 & 0.010 & 3,601 & 0.285 & 0.002 \\
\hline 2016 Drought Shock & 2,837 & 0 & 0 & 527 & 0 & 0 & 3,601 & 0.148 & 0.003 \\
\hline 2015 Flood Shock & 2,837 & 0 & 0 & 527 & 0.285 & 0.020 & 3,601 & 0 & 0 \\
\hline High Temp. Shocks & 2,837 & 0.011 & 0.004 & 527 & 0.000 & 0.000 & 3,600 & 0.057 & 0.006 \\
\hline \multicolumn{10}{|l|}{ Climate } \\
\hline Mean Rainfall & 2,837 & 2.850 & 0.004 & 527 & 2.781 & 0.011 & 3,601 & 2.839 & 0.003 \\
\hline Coef. of Variation, Rainfall & 2,837 & 0.331 & 0.001 & 527 & 0.360 & 0.002 & 3,601 & 0.335 & 0.001 \\
\hline Probability, Drought & 2,837 & 0.180 & 0.001 & 527 & 0.188 & 0.002 & 3,601 & 0.182 & 0.001 \\
\hline Probability, Flood & 2,837 & 0.134 & 0.005 & 527 & 0.172 & 0.012 & 3,601 & 0.132 & 0.005 \\
\hline Mean High Temp. Shock & 2,837 & 0.017 & 0.003 & 527 & 0.034 & 0.005 & 3,600 & 0.019 & 0.003 \\
\hline \multicolumn{10}{|l|}{ SLM Practices } \\
\hline MSD Tillage & 2,837 & 0.029 & 0.003 & 527 & 0.057 & 0.010 & 3,601 & 0.040 & 0.003 \\
\hline Legume Intercrop & 2,837 & 0.320 & 0.009 & 527 & 0.376 & 0.021 & 3,601 & 0.278 & 0.007 \\
\hline Bunds & 2,837 & 0.338 & 0.009 & 527 & 0.235 & 0.018 & 3,601 & 0.219 & 0.007 \\
\hline Green Belts & 2,837 & 0.076 & 0.005 & 527 & 0.059 & 0.010 & 3,601 & 0.095 & 0.005 \\
\hline \multicolumn{10}{|l|}{$\mathrm{SLM} \times$ Shocks $^{\mathrm{a}}$} \\
\hline Drought $\times$ MSD Tillage & & & & & & & 1,259 & 0.019 & 0.003 \\
\hline Drought $\times$ Legume Intercrop & & & & & & & 1,259 & 1,259 & 0.181 \\
\hline Drought $\times$ Bunds & & & & & & & 1,259 & 0.120 & 0.006 \\
\hline Drought $\times$ Green Belts & & & & & & & 1,259 & 0.020 & 0.003 \\
\hline Flood $\times$ MSD Tillage & & & & 150 & 0.047 & 0.017 & & & \\
\hline Flood $\times$ Legume Intercrop & & & & 150 & 0.393 & 0.040 & & & \\
\hline Flood $\times$ Bunds & & & & 150 & 0.200 & 0.033 & & & \\
\hline Flood $\times$ Green Belts & & & & 150 & 0.047 & 0.017 & & & \\
\hline
\end{tabular}

Notes: The table is constructed across all plot observations in the Long Panel and FIAS samples.

${ }^{a}$ The interaction term descriptive statistics are for those households that received a shock, as reflected in $\mathrm{N}$.

per hectare than maize yields across the samples. The 2015 flood shock also had significant negative effects on both maize yields and value per hectare in the FIAS sample, with maize yields 54 per cent lower and value per hectare 58 per cent lower. As with the drought shock, the flood shock disproportionately reduced value per hectare vis-à-vis maize yields, though to a lesser extent. High temperature shocks also reduced value per hectare in the FIAS sample, but the impact was not significant in the Long Panel sample. 
Table 3. Crop production regressions, CRE model

\begin{tabular}{|c|c|c|c|c|}
\hline & \multicolumn{2}{|c|}{ Maize yield (log) } & \multicolumn{2}{|c|}{ Value per hectare (log) } \\
\hline & Long Panel & FIAS & Long Panel & FIAS \\
\hline Dummy, 2015 & & $\begin{array}{c}-0.909^{\star \star \star} \\
(0.205)\end{array}$ & & $\begin{array}{l}-1.086^{\star \star \star} \\
(0.395)\end{array}$ \\
\hline Dummy, 2016 & $\begin{array}{c}-0.727^{\star \star \star} \\
(0.092)\end{array}$ & $\begin{array}{c}-0.804^{\star \star \star} \\
(0.188)\end{array}$ & $\begin{array}{c}-0.661^{\star \star \star} \\
(0.114)\end{array}$ & $\begin{array}{c}-0.689^{\star \star} \\
(0.293)\end{array}$ \\
\hline \multicolumn{5}{|l|}{ Climate } \\
\hline Rainfall Deviations & $\begin{array}{c}0.806^{\star} \\
(0.444)\end{array}$ & $\begin{array}{c}0.408 \\
(0.258)\end{array}$ & $\begin{array}{l}1.173^{\star \star} \\
(0.576)\end{array}$ & $\begin{array}{c}0.331 \\
(0.472)\end{array}$ \\
\hline 2016 Drought Shock & $\begin{array}{c}-1.13^{\star \star} \\
(0.463)\end{array}$ & $\begin{array}{c}-1.078^{\star \star} \\
(0.447)\end{array}$ & $\begin{array}{c}-1.891^{\star \star} \\
(0.835)\end{array}$ & $\begin{array}{c}-1.976^{\star \star} \\
(0.912)\end{array}$ \\
\hline 2015 Flood Shock & & $\begin{array}{c}-0.82^{\star \star \star} \\
(0.257)\end{array}$ & & $\begin{array}{c}-0.92^{\star \star \star} \\
(0.321)\end{array}$ \\
\hline High Temperature Shocks & $\begin{array}{c}0.052 \\
(0.198)\end{array}$ & $\begin{array}{c}-1.287 \\
(0.787)\end{array}$ & $\begin{array}{r}-0.098 \\
(0.182)\end{array}$ & $\begin{array}{l}-1.302^{\star \star \star} \\
(0.470)\end{array}$ \\
\hline \multicolumn{5}{|l|}{ SLM practices } \\
\hline MSD Tillage & $\begin{array}{c}0.245 \\
(0.215)\end{array}$ & $\begin{array}{r}-0.247 \\
(0.195)\end{array}$ & $\begin{array}{c}0.199 \\
(0.293)\end{array}$ & $\begin{array}{r}-0.285 \\
(0.349)\end{array}$ \\
\hline Legume Intercrop & $\begin{array}{r}-0.026 \\
(0.066)\end{array}$ & $\begin{array}{r}-0.128 \\
(0.096)\end{array}$ & $\begin{array}{l}0.383^{\star \star \star} \\
(0.087)\end{array}$ & $\begin{array}{l}0.352^{\star \star} \\
(0.152)\end{array}$ \\
\hline Bunds & $\begin{array}{c}0.016 \\
(0.053)\end{array}$ & $\begin{array}{r}-0.045 \\
(0.062)\end{array}$ & $\begin{array}{c}0.018 \\
(0.075)\end{array}$ & $\begin{array}{c}0.018 \\
(0.087)\end{array}$ \\
\hline Green Belts & $\begin{array}{c}-0.141^{\star} \\
(0.084)\end{array}$ & $\begin{array}{r}-0.148 \\
(0.157)\end{array}$ & $\begin{array}{r}-0.137 \\
(0.098)\end{array}$ & $\begin{array}{c}-0.149 \\
(0.241)\end{array}$ \\
\hline \multicolumn{5}{|l|}{$\mathrm{SLM} \times \mathrm{SHOCKS}$} \\
\hline Drought $\times$ MSD Tillage & $\begin{array}{c}-1.759 \\
(2.197)\end{array}$ & $\begin{array}{r}-0.602 \\
(1.650)\end{array}$ & $\begin{array}{c}-2.464 \\
(2.503)\end{array}$ & $\begin{array}{c}-0.764 \\
(2.316)\end{array}$ \\
\hline Drought $\times$ Legume Intercrop & $\begin{array}{c}0.51 \\
(0.318)\end{array}$ & $\begin{array}{l}0.796^{\star \star} \\
(0.400)\end{array}$ & $\begin{array}{l}1.189^{\star \star} \\
(0.498)\end{array}$ & $\begin{array}{l}1.467^{\star \star} \\
(0.739)\end{array}$ \\
\hline Drought $\times$ Bunds & $\begin{array}{c}-0.669^{\star \star} \\
(0.334)\end{array}$ & $\begin{array}{r}-0.604^{\star} \\
(0.311)\end{array}$ & $\begin{array}{c}-0.791^{\star} \\
(0.458)\end{array}$ & $\begin{array}{r}-0.656 \\
(0.403)\end{array}$ \\
\hline Drought $\times$ Green Belts & $\begin{array}{c}0.362 \\
(0.788)\end{array}$ & $\begin{array}{c}1.547 \\
(1.046)\end{array}$ & $\begin{array}{c}-0.062 \\
(0.709)\end{array}$ & $\begin{array}{c}0.053 \\
(0.964)\end{array}$ \\
\hline Flood $\times$ MSD Tillage & & $\begin{array}{c}0.129 \\
(0.902)\end{array}$ & & $\begin{array}{c}-0.441 \\
(0.832)\end{array}$ \\
\hline Flood $\times$ Legume Intercrop & & $\begin{array}{l}0.863^{\star \star \star} \\
(0.262)\end{array}$ & & $\begin{array}{l}0.994^{\star \star *} \\
(0.363)\end{array}$ \\
\hline Flood $\times$ Bunds & & $\begin{array}{c}0.049 \\
(0.683)\end{array}$ & & $\begin{array}{c}0.531 \\
(0.968)\end{array}$ \\
\hline Flood $\times$ Green Belts & & $\begin{array}{c}1.18^{\star} \\
(0.602)\end{array}$ & & $\begin{array}{c}0.783 \\
(0.633)\end{array}$ \\
\hline Constant & $\begin{array}{c}5.7^{\star \star} \\
(2.592)\end{array}$ & $\begin{array}{l}9.544^{\star \star \star} \\
(3.428)\end{array}$ & $\begin{array}{l}7.497^{\star \star} \\
(3.306)\end{array}$ & $\begin{array}{l}13.491^{\star \star \star} \\
(3.861)\end{array}$ \\
\hline
\end{tabular}


Table 3. Continued.

\begin{tabular}{|c|c|c|c|c|}
\hline & \multicolumn{2}{|c|}{ Maize yield (log) } & \multicolumn{2}{|c|}{ Value per hectare (log) } \\
\hline & Long Panel & FIAS & Long Panel & FIAS \\
\hline Number of observations & 4,640 & 2,735 & 6,437 & 3,346 \\
\hline$R^{2}$ (within) & 0.193 & 0.254 & 0.12 & 0.165 \\
\hline$R^{2}$ (between) & 0.41 & 0.398 & 0.406 & 0.44 \\
\hline$R^{2}$ (overall) & 0.312 & 0.33 & 0.238 & 0.273 \\
\hline
\end{tabular}

Notes: Cluster robust standard errors in parentheses.

Asterisks denote significance: ${ }^{\star} p<0.10,{ }^{* \star} p<0.05,{ }^{* \star *} p<0.01$.

With respect to the SLMs, we note that MSD tillage has no significant impacts on crop production. There remains much debate in the empirical literature on the impacts of MSD tillage alone on crop yields, with some studies suggesting that it must be adopted for at least 3 - or even 5 - years before direct benefits accrue, and/or that MSD must be used in conjunction with the two other principals of conservation agriculture. It was not possible to explore this further using our dataset, since an extremely low proportion of people stated having practiced MSD for the previous three years ( $<1.5$ per cent). Legume intercropping is the only SLM practice with a direct positive correlation, associated with 42-45 per cent higher value per hectare.

Turning next to the impacts of weather shocks and SLM interaction terms, in the FIAS sample, both the drought- and flood-legume intercrop interaction terms have positive impacts on maize yields and value per hectare. In the Long Panel, the drought-legume intercrop interactions term has a positive impact on value per hectare. Green belts have a significant positive impact under flood conditions only for maize yields. And finally, bunds have significant negative impacts under droughts for both maize and value of crop production, while conferring no benefits under floods, which helps explain the decline in such structures over time.

The benefits to legume intercropping can be quite substantial, as captured in point estimates of the linear combinations of relevant variables. For instance, under drought conditions, legume intercropping reduces maize yield losses to just 14 per cent, and value per hectare losses to 12-18 per cent. Under flood conditions, legume intercropping leads to 4 per cent higher maize yields and 7 per cent higher value per hectare. The negative impacts of stone bunds are also substantial; households with bunds had around 20 per cent lower maize yields under droughts.

Overall, the negative impacts of drought and flood shocks, and high temperature shocks in the FIAS sample, had severe negative impacts on crop yields and the value of production per hectare. SLMs have limited direct correlations with crop production, with the exception of legume intercropping in value per hectare, and only legume intercropping helped protect crop production against losses under both the drought and flood shocks, while green belts protected yields under floods.

Because many SLMs are expected to provide benefits against particularly poor production outcomes, we also investigated the impacts of SLMs and the weather shock interaction terms in reducing the probability of receiving very low yields, which we defined as yields at the 25 th percentile or below of current period yields. In general, variables 
that were significant predictors of production outcomes were also significant in reducing the probability of low production outcomes including the SLM-shock interaction terms, so we do not report results here.

There are a number of important caveats in interpreting these results. First, as noted above, the percentage of households who adopted MSD tillage and green belts and who also faced drought and flood shocks was relatively low. Under these circumstances, we likely have relatively low power to tease out the impacts of adoption under extreme weather events. Second, it is possible that we are not controlling for omitted variables that affect both SLM adoption and crop production outcomes. We have controlled for a wide range of household characteristics, the presence of externally-funded agricultural projects, and agro-climatic factors such as elevation, soil types and the coefficient of variation of rainfall, but there may be other factors affecting these decisions. We are confident that the CRE results control for time-invariant characteristics since the Wald tests of joint significance of household averages fail to reject the null hypothesis that they are jointly zero, and also because of the similarity of results to the FE specification as shown in online appendix 2. Finally, we have included other standard production inputs, such as number of weedings, inorganic fertilizer and pesticide use, all of which may be affected by omitted time-varying factors that also affect production outcomes. Our results are robust to the inclusion or exclusion of these variables, and so we include these inputs in our preferred specification.

\subsection{SLM adoption}

Table 4 presents the results for key covariates for the SLM CRE, linear probability model results. ${ }^{6}$ With respect to climate characteristics, we note that MSD is more likely to be practiced under low rainfall conditions and where high temperature shocks occur more often. On the other hand, legume intercropping is more likely to be practiced where average rainfall is high (for the Long Panel) but is less likely in locations subject to more frequent high temperature shocks. Climate variables have limited impact on adoption of bunds and green belts. Temperature shocks do have a positive impact on adoption of green belts for the FIAS sample. Also, probability of a drought reduces use of bunds in the Long Panel, consistent with the negative impact of bunds on crop production under drought conditions.

In terms of plot characteristics and agricultural implements, we note that both plot size and agricultural implements generally have positive impacts on adoption, implying that adoption is undertaken by relatively wealthy farm households. These results suggest that such farmers face lower transaction costs and opportunity costs of land, and/or that the marginal benefits to productivity are higher for these farmers, even though they are likely to be less risk-averse than those with fewer assets and smaller landholdings. Results on sandy and clay soils for the MSD regressions are somewhat counterintuitive at first glance. MSD should perform better on well-drained soils not susceptible to waterlogging. However, clay soils are found in many areas that are subject to both high drought and flood shocks, especially in the Southern Region. Additionally, external funding for promoting MSD adoption has targeted the Southern Region precisely because of the

\footnotetext{
${ }^{6}$ Full results for both the CRE and FE specifications are provided in online appendix 3. Note that coefficients on climate conditions are not directly comparable across the specifications, since in the FE, climate conditions only vary for those who have moved locations.
} 
Table 4. SLM adoption, CRE model

\begin{tabular}{|c|c|c|c|c|c|c|c|c|}
\hline & \multicolumn{2}{|c|}{ MSD } & \multicolumn{2}{|c|}{ Legume intercrop } & \multicolumn{2}{|c|}{ Bunds } & \multicolumn{2}{|c|}{ Green belts } \\
\hline & Long Panel & FIAS & Long Panel & FIAS & Long Panel & FIAS & Long Panel & FIAS \\
\hline \multicolumn{9}{|l|}{ Climate } \\
\hline Mean Rainfall, FS & $\begin{array}{c}-0.295^{\star \star \star} \\
(0.098)\end{array}$ & $\begin{array}{c}-0.306^{\star \star} \\
(0.124)\end{array}$ & $\begin{array}{c}0.228^{\star} \\
(0.135)\end{array}$ & $\begin{array}{c}0.013 \\
(0.261)\end{array}$ & $\begin{array}{l}0.429^{\star \star \star} \\
(0.143)\end{array}$ & $\begin{array}{c}0.135 \\
(0.218)\end{array}$ & $\begin{array}{r}-0.064 \\
(0.125)\end{array}$ & $\begin{array}{r}-0.023 \\
(0.108)\end{array}$ \\
\hline Prob. Drought Shock & $\begin{array}{c}0.046 \\
(0.098)\end{array}$ & $\begin{array}{r}-0.121 \\
(0.214)\end{array}$ & $\begin{array}{l}0.34 \\
(0.341)\end{array}$ & $\begin{array}{c}0.438 \\
(0.624)\end{array}$ & $\begin{array}{c}-0.578^{\star} \\
(0.333)\end{array}$ & $\begin{array}{r}-0.139 \\
(0.523)\end{array}$ & $\begin{array}{c}0.403 \\
(0.294)\end{array}$ & $\begin{array}{r}-0.063 \\
(0.256)\end{array}$ \\
\hline Prob. Flood Shock & $\begin{array}{c}-0.04 \\
(0.030)\end{array}$ & $\begin{array}{r}-0.046 \\
(0.048)\end{array}$ & $\begin{array}{c}-0.02 \\
(0.048)\end{array}$ & $\begin{array}{r}-0.033 \\
(0.066)\end{array}$ & $\begin{array}{c}0.048 \\
(0.066)\end{array}$ & $\begin{array}{r}-0.019 \\
(0.074)\end{array}$ & $\begin{array}{r}-0.018 \\
(0.063)\end{array}$ & $\begin{array}{c}0.051 \\
(0.036)\end{array}$ \\
\hline Mean High Temp. Shock & $\begin{array}{l}0.407^{\star \star} \\
(0.158)\end{array}$ & $\begin{array}{c}0.48^{\star \star} \\
(0.237)\end{array}$ & $\begin{array}{c}-0.264^{\star \star} \\
(0.132)\end{array}$ & $\begin{array}{c}-0.832^{\star \star} \\
(0.401)\end{array}$ & $\begin{array}{c}0.108 \\
(0.213)\end{array}$ & $\begin{array}{r}-0.151 \\
(0.345)\end{array}$ & $\begin{array}{c}0.221 \\
(0.205)\end{array}$ & $\begin{array}{l}0.337^{\star \star} \\
(0.157)\end{array}$ \\
\hline \multicolumn{9}{|l|}{ Plot Charact's. \& Ag. Imps. } \\
\hline Plot Size (logs) & $\begin{array}{r}-0.002 \\
(0.003)\end{array}$ & $\begin{array}{r}-0.001 \\
(0.007)\end{array}$ & $\begin{array}{l}0.064^{\star \star \star} \\
(0.007)\end{array}$ & $\begin{array}{l}0.085^{\star \star \star} \\
(0.012)\end{array}$ & $\begin{array}{l}0.035^{\star \star \star} \\
(0.007)\end{array}$ & $\begin{array}{l}0.038^{\star \star \star} \\
(0.009)\end{array}$ & $\begin{array}{l}0.015^{\star \star \star} \\
(0.004)\end{array}$ & $\begin{array}{c}0.008 \\
(0.006)\end{array}$ \\
\hline Ag. Implements Index & $\begin{array}{l}0.071^{\star \star \star} \\
(0.022)\end{array}$ & $\begin{array}{l}0.125^{\star \star \star} \\
(0.042)\end{array}$ & $\begin{array}{c}0.011 \\
(0.050)\end{array}$ & $\begin{array}{c}0.112 \\
(0.075)\end{array}$ & $\begin{array}{l}0.184^{\star \star \star} \\
(0.065)\end{array}$ & $\begin{array}{l}0.247^{\star \star \star} \\
(0.074)\end{array}$ & $\begin{array}{c}0.039 \\
(0.040)\end{array}$ & $\begin{array}{r}-0.001 \\
(0.045)\end{array}$ \\
\hline Slope & $\begin{array}{c}-0.024^{\star \star \star} \\
(0.008)\end{array}$ & $\begin{array}{c}-0.026^{\star \star} \\
(0.011)\end{array}$ & $\begin{array}{c}0.032 \\
(0.025)\end{array}$ & $\begin{array}{c}0.049 \\
(0.032)\end{array}$ & $\begin{array}{l}0.052^{\star \star} \\
(0.022)\end{array}$ & $\begin{array}{c}0.013 \\
(0.021)\end{array}$ & $\begin{array}{c}0.004 \\
(0.014)\end{array}$ & $\begin{array}{c}-0.01 \\
(0.010)\end{array}$ \\
\hline Dummy, Sandy Soil & $\begin{array}{c}-0.016^{\star \star \star} \\
(0.006)\end{array}$ & $\begin{array}{r}-0.014 \\
(0.010)\end{array}$ & $\begin{array}{r}-0.015 \\
(0.015)\end{array}$ & $\begin{array}{l}0 \\
(0.027)\end{array}$ & $\begin{array}{r}-0.016 \\
(0.016)\end{array}$ & $\begin{array}{r}-0.003 \\
(0.020)\end{array}$ & $\begin{array}{c}0.016 \\
(0.012)\end{array}$ & $\begin{array}{c}0.008 \\
(0.009)\end{array}$ \\
\hline Dummy, Clay Soil & $\begin{array}{l}0.015^{\star \star} \\
(0.007)\end{array}$ & $\begin{array}{c}0.011 \\
(0.011)\end{array}$ & $\begin{array}{c}-0.035^{\star \star} \\
(0.014)\end{array}$ & $\begin{array}{c}-0.058^{\star \star \star} \\
(0.018)\end{array}$ & $\begin{array}{c}-0.013 \\
(0.020)\end{array}$ & $\begin{array}{r}-0.009 \\
(0.027)\end{array}$ & $\begin{array}{c}0.005 \\
(0.012)\end{array}$ & $\begin{array}{c}0.006 \\
(0.011)\end{array}$ \\
\hline Constant & $\begin{array}{l}1.177^{\star \star \star} \\
(0.248)\end{array}$ & $\begin{array}{l}1.304^{\star \star \star} \\
(0.382)\end{array}$ & $\begin{array}{l}-0.12 \\
(0.345)\end{array}$ & $\begin{array}{c}0.587 \\
(0.691)\end{array}$ & $\begin{array}{r}-0.526 \\
(0.399)\end{array}$ & $\begin{array}{r}-0.006 \\
(0.604)\end{array}$ & $\begin{array}{r}-0.007 \\
(0.365)\end{array}$ & $\begin{array}{r}-0.026 \\
(0.306)\end{array}$ \\
\hline Number of Observations & 6,437 & 3,346 & 6,437 & 3,346 & 6,437 & 3,346 & 6,437 & 3,346 \\
\hline$R^{2}$ (within) & 0.019 & 0.04 & 0.055 & 0.075 & 0.074 & 0.117 & 0.053 & 0.046 \\
\hline$R^{2}$ (between) & 0.534 & 0.604 & 0.496 & 0.48 & 0.237 & 0.296 & 0.177 & 0.224 \\
\hline$R^{2}$ (overall) & 0.278 & 0.32 & 0.304 & 0.257 & 0.146 & 0.18 & 0.142 & 0.11 \\
\hline
\end{tabular}

Notes: Cluster robust standard errors in parentheses.

Asterisks denote significance: ${ }^{\star} p<0.10,{ }^{\star \star} p<0.05,{ }^{\star \star \star} p<0.01$. 
region's vulnerability to weather shocks. These counterintuitive results nonetheless help explain the limited impacts on maize yields and value of crop production.

To summarize, the probability of flood and drought shocks generally do not have significant impacts on SLM adoption, though expected temperature shocks do increase MSD and green belts while having a negative impact on legume intercropping. The lack of significance of exposure to flood and drought shocks is particularly unfortunate for legume intercropping, which has a positive impact on crop production under both droughts and floods. Even more unfortunate is the fact that legume intercropping has declined over time.

\section{Concluding comments}

Given that extreme weather events are likely to increase - both droughts and floods this study provides three key pieces of evidence. The first is that crop outcomes were severely affected by the droughts in 2016 and floods in 2015. Second, evidence suggests that certain SLM techniques, particularly legume intercropping and - to a lesser extent green belts, can offset the impacts of extreme weather events, making farmers more resilient. Yet, adoption of legume intercropping has decreased over time in our sample, and though adoption of green belts is increasing, it remains limited at just 9 per cent. Third, farmers who adopt legume intercropping and green belts have larger landholdings and greater wealth levels, suggesting that costs of adopting - opportunity costs of land taken out of production, cash costs to purchase legume seeds, vetiver grass or suitable trees for tree belts, costs of protecting the establishment of green belts and maintaining them - are currently prohibitive for poorer and more vulnerable farm households.

From the above, we can draw some tentative policy implications. First, our evidence contributes to that of other studies that find positive benefits from legume intercropping on crop production outcomes both under normal conditions as well as under both droughts and floods. Farmers prefer options that increase yields under all rainfall conditions, and legume intercropping appears to be one of the few options that does so. This is particularly important for farmers in areas subject to high probabilities of both droughts and floods, such as farmers located in the Southern Region in Malawi. Secondly, our evidence also contributes to a fairly large body of evidence that suggests that MSD offers limited benefits to farmers. While more can be done to understand why, the combined results suggest that policymakers and donor-funded project managers should carefully re-think the strong emphasis on conservation agriculture in Malawi, and instead consider shifting more towards legumes, and to a lesser extent, green belts. Similarly, farmers are still very exposed to negative impacts of droughts and floods, with severe losses experienced under these climate extremes. It may be useful to consider other options that increase both 'average' productivity and resilience to extremes, such as irrigation schemes and heat resistant seeds.

A potential concern about endogeneity of the direct impact of SLM adoption and crop outcomes remains. Though we have run CRE and FE models and included a wide range of household and community control variables, certain time-varying omitted characteristics may explain both adoption of SLM and crop outcomes. Yet, there were no defensible instruments; additionally, we would have needed at least four such instruments.

Finally, we also learned quite a bit about the difficulty of specifying flood and drought shocks, and even determining the best rainfall data sources to use to create longterm climate characteristics. While some variables created across different data sources 
performed similarly, others did not. We chose the ones that worked best to explain our outcomes. Much remains to be done to systematically evaluate the performance of both data sources and specific variables to measure extreme weather events.

Supplementary material. The supplementary material for this article can be found at https://doi.org/10. 1017/S1355770X20000455.

Acknowledgements. We gratefully acknowledge financial support from the World Bank Research Support Budget and the World Bank Living Standards Measurement Study - Integrated Surveys on Agriculture (LSMS-ISA) initiative.

\section{References}

Alfani F, Arslan A, McCarthy N, Cavatassi R and Sitko N (2019) Climate-change vulnerability in rural Zambia: the impact of an El Nino-induced shock on income and productivity. ESA Working Papers 288949, FAO, Rome.

Arslan A, McCarthy N, Lipper L, Asfaw S, Cattaneo A and Kokwe M (2015) Climate smart agriculture? Assessing the adaptation implications in Zambia. Journal of Agricultural Economics 66, 753-780.

Asfaw S, McCarthy N, Lipper L, Arslan A and Cattaneo A (2016) What determines farmers' adaptive capacity? Empirical evidence from Malawi. Food Security 8, 1-22.

Battese GE (1997) A note on the estimation of Cobb-Douglas production functions when some explanatory variables have zero values. Journal of Agricultural Economics 48, 250-252.

Belloumi M (2014) Investigating the impact of climate change on agricultural production in eastern and southern African countries. AGRODEP Working Paper 0003, African Growth and Development Policy Modeling Consortium, Dakar, Senegal.

Benin S (2006) Policies and programs affecting land management practices, input use, and productivity in the highlands of Amhara Region, Ethiopia. In Pender J, Place F and Ehui S (eds), Strategies for Sustainable Land Management in the East African Highlands, Washington, DC: IFPRI, pp. 217-256.

Blanc É (2012) The impact of climate change on crop yields in Sub-Saharan Africa. American Journal of Climate Change 1, 1-13.

Blanco H and Lal R (2008) Principles of Soil Conservation and Management. New York: Springer.

Chavas J-P and Holt MT (1996) Economic behavior under uncertainty: a joint analysis of risk preferences and technology. The Review of Economics and Statistics 76, 329-335.

Dalezios NR, Dunkel Z and Eslamian S (2017) Meteorological drought indices: definitions. In Eslamian $S$ and Eslamian FA (eds), Handbook of Drought and Water Scarcity: Principles of Drought and Water Scarcity. Boca Raton, FL: CRC Press, pp. 27-45.

Dutilly-Diane C, Sadoulet E and de Janvry A (2003) How improved natural resource management in agriculture promotes the livestock economy in the Sahel. Journal of African Economics 12, 343-370.

Hao Z, Youan X, Xia Y, Hao F and Singh VP (2017) An overview of drought monitoring and prediction systems at regional and global scales. Bulletin of the American Meteorological Society 98, 1879-1896.

Hardaker JB, Huirne RBM, Anderson JR and Lien G (2004) Coping with Risk in Agriculture, 2nd Edn. Wallingford, UK and Cambridge, MA: CABI Publishing.

Hatfield JL (2016) Increased temperatures have dramatic effects on growth and grain yield of three maize hybrids. Agricultural \& Environmental Letters 1, 1-5.

Hurley T (2010) A review of agricultural production risk in the developing world. Harvest Choice Working Paper 11, International Food Policy Research Institute, Washington, DC.

Just RE and Zilberman D (1983) Stochastic structure, farm size and technology adoption in developing agriculture. Oxford Economic Papers 35, 307-328.

Kassie M, Pender J, Yesuf M, Köhlin G, Bluffstone R and Mulugeta E (2008) Estimating returns to soil conservation adoption in the northern Ethiopian highlands. Agricultural Economics 38, 213-232.

Kassie M, Zikhali P, Pender J and Köhlin G (2010) The economics of sustainable land management practices in the Ethiopian highlands. Journal of Agricultural Economics 61, 605-627.

Kassie M, Teklewold H, Jaleta M, Marenya P and Erenstein O (2015) Understanding the adoption of a portfolio of sustainable intensification practices in eastern and Southern Africa. Land Use Policy $\mathbf{4 2}$, $400-411$. 
Kato E, Ringler C, Yesuf M and Bryan E (2011) Soil and water conservation technologies: a buffer against production risk in the face of climate change? Insights from the Nile basin in Ethiopia. Agricultural Economics 42, 593-604.

Lewbel A (2012) Using heteroscedasticity to identify and estimate mis-measured and endogenous regressor models. Journal of Business \& Economic Statistics 30, 67-80.

Malawi Vulnerability Assessment Committee (MVAC) (2015) National food and nutrition forecast, April 2015 to March 2016. Bulletin No. 11/15 Volume 1. Government of Malawi, Lilongwe.

Malawi Vulnerability Assessment Committee (MVAC) (2016) National food and nutrition forecast, April 2016 to March 2017. Bulletin No. 12/16 Volume 1. Government of Malawi, Lilongwe.

Mattee AZ, Mussa KR, Mwaseba DL, Mahonge CP and Nsenga JV (2015) Factors in smallholder farmers' vulnerability to climate change impacts in the Uluguru Mountains, Morogoro, Tanzania. In Lal R, Singh BR, Mwaseba DL, Kraybill DL, Eik DO and Hansen LO (eds), Sustainable Intensification to Advance Food Security and Enhance Climate Resilience in Africa. Switzerland: Springer, pp. 185-200.

McCarthy N, Lipper L and Branca G (2011) Climate-smart agriculture: smallholder adoption and implications for climate change adaptation and mitigation. Mitigation of Climate Change in Agriculture Working Paper 3, FAO, Rome, Italy.

McCarthy N, Kilic T, de la Fuente A and Brubaker JM (2018) Shelter from the storm? Household level impacts of, and responses to, the 2015 floods in Malawi. Economics of Disasters and Climate Change 2, 237-258.

Merz B, Thieken AH and Gocht M (2007) Flood risk mapping at the local scale: concepts and challenges. In Begum S, Stive MJF and Hall JW (eds), Flood Risk Management in Europe. Dordrecht, The Netherlands: Springer, pp. 231-251.

Micheler JD, Baylis K, Arends-Kuenning M and Mazvimavi K (2019) Conservation agriculture and climate resilience. Journal of Environmental Economics and Management 93, 148-169.

Nicholson SE, Nash DJ, Chase BM, Grab SW, Shanahan TM, Verschuren D and Umer M (2013) Temperature variability over Africa during the last 2000 years. The Holocene 23, 1085-1094.

Nizalava $\mathbf{O}$ and Mirtazashvili I (2016) Exogenous treatment and endogenous factors: vanishing of omitted variable bias on the interaction term. Journal of Econometric Methods 5, 71-77.

Nkonya E, Place F, Kato E and Mwanjololo M (2015) Climate risk management through sustainable land management in sub-Saharan Africa. In Lal R, Singh BR, Mwaseba DL, Kraybill DL, Hansen DO and Eik LO (eds), Sustainable Intensification to Advance Food Security and Enhance Climate Resilience in Africa. Switzerland: Springer, pp. 75-111.

Pender J and Gebremedhin B (2008) Determinants of agricultural and land management practices and impacts on crop production and household income in the highlands of Tigray, Ethiopia. Journal of African Economies 17, 395-450.

Ramaswami B (1992) Production risk and optimal input decisions. American Journal of Agricultural Economics 74, 860-869.

Ricker-Gilbert J, Jumbe C and Chamberlin J (2014) How does population density influence agricultural intensification and productivity? Evidence from Malawi. Food Policy 48, 114-128.

Schlenker W and Lobell DB (2010) Robust negative impacts of climate change on African agriculture. Environmental Research Letters 5, 014010.

Schunck R (2013) Within and between estimates in random effects models: advantages and drawbacks of correlated random effects and hybrid models. The Stata Journal 13, 65-76.

Steward PR, Dougill AJ, Thierfelder C, Pittelkow CM, Stringer LC, Kudzala M and Shackelford GE (2018) The adaptive capacity of maize-based conservation agriculture systems to climate stress in tropical and subtropical environments: a meta-regression of yields. Agriculture, Ecosystems \& Environment 251, 194-202.

Venäläinen A, Pilli-Sihvola K, Tuomenvirta H, Ruuhela R, Kululanga E, Mtilatila L, Kanyanga J and Nkomoki J (2016) Analysis of the meteorological capacity for early warnings in Malawi and Zambia. Climate and Development 8, 190-196.

Ward PS, Bell AR, Droppelmann K and Benton TG (2018) Early adoption of conservation agriculture practices: understanding partial compliance in programs with multiple adoption decisions. Land Use Policy 70, 27-37.

Wineman A, Mason N, Ochieng J and Kirimi L (2017) Weather extremes and household welfare in rural Kenya. Food Security 9, 281-300. 
Wooldridge J (2010) Econometric Analysis of Cross Section and Panel Data. Cambridge, MA: The MIT Press.

World Bank (2016) Republic of Malawi: poverty assessment. Poverty and Equity Global Practice Africa Region Report, Washington, DC: World Bank Group.

Cite this article: McCarthy N, Kilic T, Brubaker J, Murray S, de la Fuente A (2021). Droughts and floods in Malawi: impacts on crop production and the performance of sustainable land management practices under weather extremes. Environment and Development Economics 26, 432-449. https://doi.org/10.1017/ S1355770X20000455 